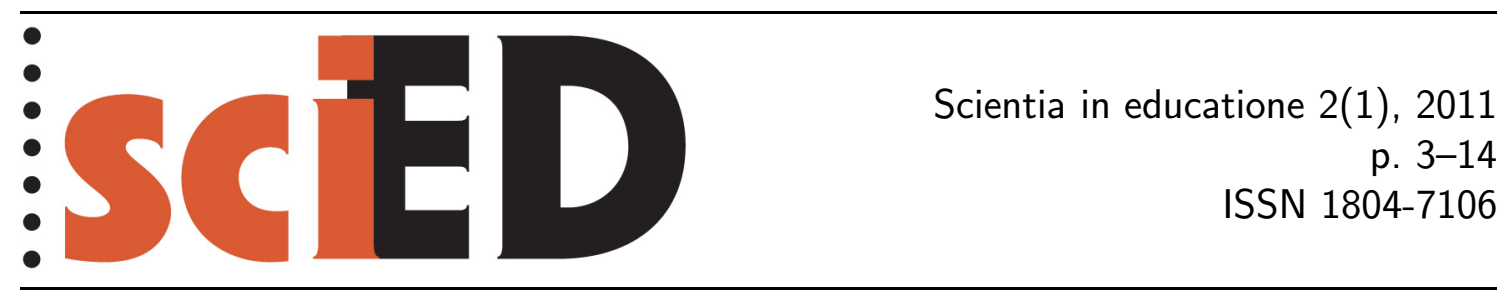

\title{
Konstrukční výzkum (design-based research) v přírodovědných didaktikách
}

\author{
Josef Trna
}

\begin{abstract}
Abstrakt
Teoretická studie s praktickou ukázkou prezentuje konstrukční výzkum (angl. design-based research) v přírodovědných didaktikách. V první části jsou vymezeny pojmy konstrukční přístup a konstrukční výzkum. Konstrukční výzkum je novým trendem v didaktickém výzkumu. Tuto výzkumnou metodu lze stručně charakterizovat jako cyklus - analýza praktického problému; vývoj řešení; testování řešení v praxi; reflexe a zobecnění. V druhé části je uveden konkrétní př́klad konstrukčního výzkumu v didaktice fyziky (přírodovědy). Jako vzdělávací obsah je použito jednoduché experimentování s lidským tělem. Ke zkvalitnění své výuky potřebují př́rodovědní učitelé metody založené na pedagogickém výzkumu. Konstrukční výzkum a akční výzkum, jenž je součástí konstrukčního výzkumu, by měly být zařazeny také do přípravného i dalšího vzdělávání učitelů prŕírodovědných př̀edmětů.
\end{abstract}

Klíčová slova: konstrukční přístup, konstrukční výzkum, přírodovědné vzdělávání, příprava učitelů, design-based research.

\section{Design-based Research in Science Subject Didactics}

\begin{abstract}
A theoretical study with a practical example presents design-based research in science subject didactics. Firstly, key terms design approach and design-based research are described. Design-based research is a new trend in educational research. The research method can be described as a cycle: analysis of a practical problem, development of solutions, iterative testing of solutions, reflection and generalization. Secondly, a practical example of designbased research in didactics of physics (science) is presented. The applied teaching content is a hands-on experiment with the human body. Science teachers need research-based innovative educational methods for the improvement of their teaching. Design-based research and action research, which is a part of design-based research, should be implemented into pre-service and in-service science teacher training.
\end{abstract}

Key words: design approach, design-based research, science education, teacher training. 


\section{1 ÚVOD}

Přírodovědným didaktikám je často vyčítána jejich nedostatečně propracovaná a neukotvená výzkumná metodologie. Na otázku, jaké specifické výzkumné přristupy a metody přírodovědné didaktiky používají, je často nelehké odpovědět. Důvodem je hraniční postavení těchto vědeckých disciplín mezi pedagogikou, psychologií, sociologií a vlastním oborem, či dokonce více obory (ostatní přírodní vědy a matematika). Je proto logické, že oborové didaktiky aplikují zcela či částečně výzkumné přístupy a metody těchto disciplín, nejvíce pedagogiky a psychologie. Odpovědí by tedy mohlo být, že př́rodovědné didaktiky vlastní výzkumné přistupy a metody ve skutečnosti nepotřebují.

Každá samostatná a emancipovaná vědecká disciplína, tedy i přírodovědná didaktika, by však vedle předmětu výzkumu měla být charakterizována i svojí specifickou metodologií. Tato studie se pokouší stručně prezentovat konstrukční výzkum (design-based research) jako specifický výzkumný přístup a metodu přírodovědných, ale i jiných oborových didaktik, na př́kladu didaktiky fyziky.

\section{ZÁKLADNÍ A APLIKOVANÝ VÝZKUM V PŘÍRODOVĚDNÝCH DIDAKTIKÁCH}

Z různých objektivních i subjektivních důvodů zatím výzkum v přírodovědných didaktikách u nás ani ve světě nedosahuje standardní úrovně řady jiných tradičních vědeckých disciplín. Nebudeme nyní tyto důvody analyzovat, ale zaměříme se na možnosti zlepšení tohoto stavu. Reeves (2006) uvádí jako hlavní tři obecné problémy výzkumu v oborové didaktice:

- nejasnost postavení a role jejího základního a aplikovaného výzkumu,

- nízká kvalita výzkumných prací,

- výsledky výzkumu poskytují učitelům v praxi často nedostatečné nebo matoucí návody.

Těmito problémy trpí všechny přírodovědné didaktiky.

Mnozí konzervativní oboroví didaktici se drží klasické linie vedoucí od základního k aplikovanému výzkumu a stále trvají na existenci ostré hranice, jež tyto výzkumy odděluje (Merrill et al., 1996). Začíná se ale prosazovat názor, že toto dělení je nepřirozené; navíc je třeba více se zaměřit na požadavky praxe. Vztah základního a aplikovaného výzkumu výstižně popisuje schéma s tzv. Pasteurovým kvadrantem (viz tab. 1), který poprvé uvedl Stokes (1997).

Tab. 1: Pasteurův kvadrant podle Stokese (1997)

\begin{tabular}{|c|c|c|c|}
\hline & \multicolumn{3}{|c|}{$\begin{array}{c}\text { Aplikovaný výzkum } \\
\text { inspirovaný úvahami o využití }\end{array}$} \\
\hline \multirow{2}{*}{$\begin{array}{c}\text { Základní } \\
\text { výzkum } \\
\text { inspirovaný } \\
\text { úvahami } \\
\text { o podstatě jevů }\end{array}$} & ANO & NE & ANO \\
\cline { 2 - 4 } & (čistý základní výzkum) & $\begin{array}{c}\text { Pasteur } \\
\text { (aplikací inspirovaný } \\
\text { základní výzkum) }\end{array}$ \\
\cline { 2 - 4 } & - & $\begin{array}{c}\text { Edison } \\
\text { (čistý aplikovaný výzkum) }\end{array}$ \\
\hline
\end{tabular}


Pasteurův kvadrant v uvedeném schématu organicky propojuje základní a aplikovaný výzkum. Současné tendence v mnoha vědních disciplínách, které mají těsnou vazbu na praxi, vedou k realizaci „aplikací inspirovaného základního výzkumu“ (viz Pasteurův kvadrant $\mathrm{v}$ tab. 1). Výzkum v přírodovědných didaktikách by měl tyto tendence akceptovat.

\section{VÝZKKUMNÉ CÍLE V PŘíRODOVĚDNÝCH DIDAKTIKÁCH}

Velmi významným problémem výzkumníků v přírodovědných didaktikách (a nejde jen o ně) je nerozlišování výzkumných záměrů a cílů a výzkumných metod a nástrojů. Reeves (2000) uvádí negativní př́íklad, kdy začínající výzkumník prezentuje své zaměření bud' na kvantitativní, nebo kvalitativní metodu výzkumu, aniž se nejdřive zamýšlí nad záměrem a cílem svého výzkumu. Podle Reevese (2000) je vhodné stanovit šest základních typů výzkumných cílů (záměrů), viz tab. 2.

V souladu s uvedeným tř́iěním výzkumných cílů (záměrů) navrhujeme analogicky tř́idit i typy výzkumů v př́rodovědných didaktikách:

1. teoretický výzkum

2. empirický výzkum

3. interpretační výzkum

4. postmoderní výzkum

5. vývojový výzkum

6. akční výzkum

Z vědeckých prací v přírodovědných didaktikách je zřejmé, že důraz je v současnosti kladen na empirický výzkum. Je to dáno mj. i obdobnou aktuální tendencí v pedagogice a i v jiných společenskovědních disciplínách. Do pozadí tak ustupuje tradiční teoretický výzkum. Další typy výzkumu jsou realizovány v malé míře, nebo nejsou dokonce za výzkum považovány (např. akční výzkum). Tato tendence výrazně omezuje šíri výzkumu v př́rodovědných didaktikách, především odtrhává výzkum od vývoje a od aplikační praxe. Vzniklou negativní situaci může napravit uznání dalších typů výzkumů za plnoprávné a podpora jejich rozvoje. To platí zejména o vývojovém a akčním výzkumu.

\section{VÝZKUMNÉ METODY V PŘíRODOVĚDNÝCH DIDAKTIKÁCH}

Nejdříve je třeba mít zcela ujasněný cíl (záměr) výzkumu (viz odst. 3), teprve pak je možno volit vhodné výzkumné metody. Podle Reevese (2000) je účelné klasifikovat šest základních typů výzkumných metod podle zaměření jejich aplikace.

Uvedené výzkumné metody lze $\mathrm{v}$ přrírodovědných didaktikách doplnit o další, můžeme je ale považovat za bázi. 
Tab. 2: Typologie výzkumných cílů (záměrů) v oborových didaktikách podle Reevese (2000)

\begin{tabular}{|c|c|}
\hline $\begin{array}{l}\text { Teoretické } \\
\text { (theoretical) cíle }\end{array}$ & $\begin{array}{l}\text { Zaměření na vysvětlení jevů prostřednictvím logické } \\
\text { analýzy a syntézy teorií, principů a výsledků jiných typů } \\
\text { výzkumů, především empirických studií; vyžaduje } \\
\text { vysokou úroveň syntézy a zobecnění; předpokládá } \\
\text { dlouhodobou vědeckou práci. }\end{array}$ \\
\hline $\begin{array}{l}\text { Empirické } \\
\text { (empirical) cíle }\end{array}$ & $\begin{array}{l}\text { Zaměření na zjištování stavu fungování vzdělávacího } \\
\text { systému (výkonnost, hodnocení, sociální interakce, } \\
\text { vzdělávací design aj.), stanovení účinků faktorů } \\
\text { vzdělávání nebo aspektů technologických inovací } \\
\text { v kontrolovaných podmínkách s využitím kvantitativních } \\
\text { výzkumných metod; v současnosti je populární a mohou } \\
\text { se mu věnovat začínající výzkumníci. }\end{array}$ \\
\hline $\begin{array}{l}\text { Interpretační } \\
\text { (interpretivist) } \\
\text { cíle }\end{array}$ & $\begin{array}{l}\text { Zaměření na popis a výklad prvků a jevů ve vzdělání } \\
\text { (výkonnost, hodnocení, sociální interakce, inovace aj.) } \\
\text { s využitím kvalitativních výzkumných metod; narůstá } \\
\text { popularita, třebaže je občas kritizováno (statistická } \\
\text { neprůkaznost apod.). }\end{array}$ \\
\hline $\begin{array}{l}\text { Postmoderní } \\
\text { (postmodern) } \\
\text { cíle }\end{array}$ & $\begin{array}{l}\text { Zaměření na kritické zkoumání stavu a podmínek } \\
\text { současného vzdělávacího systému, s cílem odhalit skryté } \\
\text { problémy z hlediska alternativních názorů } \\
\text { (multikulturnost, gender aj.); výzkum je vzácný, protože } \\
\text { se mu věnuje málo výzkumníků i v důsledku malé } \\
\text { poptávky po těchto výzkumech. }\end{array}$ \\
\hline $\begin{array}{l}\text { Vývojové } \\
\text { (development) } \\
\text { cíle }\end{array}$ & $\begin{array}{l}\text { Zaměření na dvojitý cíl: rozvinout tvưrčí přístupy k řešení } \\
\text { problematiky zefektivnění vzdělávaní a současně budovat } \\
\text { konkrétní postupy a nástroje, které mohou vést k tomuto } \\
\text { rozvoji; rozvoj tohoto výzkumu, který je také označován } \\
\text { jako konstrukční experiment či formativní výzkum, má } \\
\text { aktuální podporu i díky svému propojení s praxí. }\end{array}$ \\
\hline $\begin{array}{l}\text { Akční (action) } \\
\text { cíle }\end{array}$ & $\begin{array}{l}\text { Zaměření na konkrétní projekt (produkt, technologický } \\
\text { prvek), který má zefektivnit vzdélávání; je blízký } \\
\text { vývojovému výzkumu, je zde ale kladen malý důraz na } \\
\text { zobecnění pro rozvoj teorie, což bývá akčnímu výzkumu } \\
\text { vytýkáno, a ten je pak považován jen za hodnotící fázi } \\
\text { jiného výzkumu; hlavním cílem je řešení konkrétního } \\
\text { problému, na určitém místě a v krátkém časovém úseku; } \\
\text { je považován za legitimní formu výzkumu za předpokladu, } \\
\text { že zpráva je publikována a mǔže být využita i v jiném } \\
\text { výzkumu. }\end{array}$ \\
\hline
\end{tabular}


Tab. 3: Typologie výzkumných metod v oborových didaktikách podle Reevese (2000)

\begin{tabular}{|l|l|}
\hline $\begin{array}{l}\text { Kvantitativní } \\
\text { (quantitative) } \\
\text { metody }\end{array}$ & $\begin{array}{l}\text { Experimentální, kvaziexperimentální, korelační aj.; } \\
\text { shromažd'ování kvantitativních dat a jejich analýzy } \\
\text { s využitím statistik (např. analýza rozptylu výsledků } \\
\text { didaktických testů). }\end{array}$ \\
\hline $\begin{array}{l}\text { Kvalitativní } \\
\text { (qualitative) } \\
\text { metody }\end{array}$ & $\begin{array}{l}\text { Pozorování, případové studie, rozhovory aj.; získávání } \\
\text { kvalitativních dat a jejich analýzy pomocí etnografických } \\
\text { postupů (např. pozorování účastníka ve výuce). }\end{array}$ \\
\hline $\begin{array}{l}\text { Kritické (critical } \\
\text { theory) metody }\end{array}$ & $\begin{array}{l}\text { Rozkladová analýza teorií a technologií; systémové } \\
\text { vyhledávání rozporů, skrytých problémů (např. kritická } \\
\text { analýza disjunktního třídéní fenoménů). }\end{array}$ \\
\hline $\begin{array}{l}\text { Historické } \\
\text { (historical) } \\
\text { metody }\end{array}$ & $\begin{array}{l}\text { Objektivní a přesná rekonstrukce minulosti, často ve } \\
\text { vztahu k obhajitelnosti hypotézy (např. to, že John } \\
\text { Dewey byl zakladatel pragmatické pedagogiky). }\end{array}$ \\
\hline $\begin{array}{l}\text { Přehledové } \\
\text { (literature } \\
\text { review) metody }\end{array}$ & $\begin{array}{l}\text { Rešerše se syntézou, které primárně zahrnují analýzu } \\
\text { a integraci jiných forem výzkumu (např. frekvenční } \\
\text { analýza a metaanalýza). }\end{array}$ \\
\hline $\begin{array}{l}\text { Kombinované } \\
\text { (mixed-methods) } \\
\text { metody }\end{array}$ & $\begin{array}{l}\text { Kombinace různých metod, obvykle kvantitativní } \\
\text { a kvalitativní z důvodu ověrení výzkumných zjištění } \\
\text { (např. pretest a posttest kombinovaný s pozorováním } \\
\text { ve tř́dě). }\end{array}$ \\
\hline
\end{tabular}

\section{KONSTRUKČNÍ PŘÍSTUP (DESIGN APPROACH) V PŘÍRODOVĚDNÝCH DIDAKTIKÁCH}

Přírodovědné didaktiky realizují výzkum i vývoj, většina je však podstatou oborové didaktiky zaměřena především do aplikační sféry, včetně inovací. Proto je užitečné zjistit, jak obdobný metodologický problém vztahu výzkumu a vývoje řeší jiné disciplíny. Analogickým př́kladem je situace v technických disciplínách, též silně spjatých s praxí, kde má významné postavení konstrukční přístup (design approach). Jeho podstatou je orientace na tvorbu (konstrukci) nového produktu, která přináší řešení problémů, jež jsou dosud řešeny jen částečně a př́íslušné nástroje a metody jsou v počátcích. Konstrukční přistup je aplikován v široké řadě oblastí během procesů tvorby a v průběhu praktického využití.

Na tomto místě je nutno provést terminologickou úvahu. V anglické terminologii je užíván termín „design“, jehož dřivější překlad do češtiny byl blíž k pouhému "desénu“ (vnější úpravě) produktu. Dnes však tento termín odpovídá „projektu“ či „konstrukci“ (vnitřní struktuře a funkci) tohoto produktu. Z důvodu dosavadního využití různých českých synonym jsme pro překlad „design“ zvolili termín „konstrukce (konstrukční)“, který budeme nadále užívat. Je zřejmé, že tato volba vyvolává diskusi o vhodnosti termínu „konstrukční“, kterou zde nebudeme rozvádět.

Konstrukční přístup k řešení problémů je většinou interdisciplinární a integrační. To je tendence, která se postupně prosazuje $\mathrm{v}$ př́rodovědných oborových didaktikách, kde se jeví jako prospěšné ustavit mezioborovou přírodovědnou didaktiku (Trna, 2005). Právě konstrukční př́ístup by se pro tuto mezioborovou př́rodovědnou didaktiku mohl stát specifickým. 


\section{KONSTRUKČNÍ VÝZKUM (DESIGN-BASED RESEARCH) V PŘÍRODOVĚDNÝCH DIDAKTIKÁCH}

Použijeme-li v přírodovědných didaktikách konstrukční přístup, pak je zřejmé, že cíle příslušného výzkumu budou především vývojové a akční (srovnej odst. 3). Těmto cílům odpovídá řada výzkumných metod; obvykle jsou kombinované (srovnej odst. 4). Zavedení konstrukčního přístupu do přírodovědných didaktik vede $\mathrm{k}$ ustanovení a rozvoji nového typu výzkumu, který nazýváme konstrukčni výzkum (angl. designbased research). Při ustanovení nového typu výzkumu v oborových didaktikách se nevyhneme problému vytvoření jeho názvu a zejména co nejpřesnější charakteristiky. V souladu s výše uvedenou terminologickou úvahou (odst. 5) jsme navrhli termín konstrukční výzkum (design-based research), který - pro jeho stručnost a názornost - budeme nadále užívat. Upozorňujeme na dosavadní neustálenost označení tohoto výzkumu v zahraniční (angl. design-based research, design research, educational design research) a zejména u nás. Předpokládáme, že dojde k odborné diskusi, která tuto problematiku dořeší.

\subsection{DUALISMUS KONSTRUKČNíHO VÝZKUMU}

Podle výše uvedeného třídění výzkumných cílů (odst. 3) má konstrukční výzkum hlavní cíle vývojové a akční. Podle našeho názoru ve vztahu „výzkum-vývoj“ či „základní-aplikovaný“ mají cíle konstrukčního výzkumu v přírodovědných didaktikách dualistický charakter:

1. výzkumné řešení obecné problematiky rozvoje přírodovědného vzdělávání,

2. vývojová tvorba specifických konkrétních postupů a nástrojů, které mohou vést k rozvoji praxe prř́rodovědného vzdělávání.

Podstatou dualismu těchto dvou výzkumně-vývojových cílů konstrukčního výzkumu je jejich neoddělitelnost a vzájemná podmíněnost. Konstrukční výzkum tak plně vyhovuje aktuálnímu požadavku realizace ,aplikací inspirovaného základního výzkumu" v tzv. Pasteurově kvadrantu (viz odst. 2). Je třeba zdůraznit, že konstrukční výzkum je prvotně výzkumem, jehož hlavním cílem je objevování nových poznatků. Nejde tedy jen o pouhý vývoj. Je však těsně spjatý a podněcovaný aplikační sférou, pro kterou vyvíjí nové metody a prostředky.

Objevuje se otázka, kdo může realizovat konstrukční výzkum. Půjde-li o jedince, pak musí mít výzkumné i vývojové kompetence s bohatými zkušenostmi ze vzdělávací praxe. Nepůjde tedy o samostatného začínajícího výzkumníka. Složitost narůstajících poznatků i praktických problémů ve vzdělávání si při konstrukčním výzkumu vyžaduje týmovou spolupráci. V týmu musí být zastoupeni pracovníci s výše uvedenými kompetencemi. V konkrétní podobě to může být např. dvojice výzkumníků, složená z oborového didaktika a zkušeného pedagoga z praxe. Náročnost výzkumných metod si vyžaduje př́padné posílení týmu o odborníka na výzkumné metody (designér, statistik).

\subsection{STRUKTURA KONSTRUKČNíHO VÝZKUMU}

Konstrukční výzkum s vývojovými a akčními cíli se liší od jiných druhů výzkumů. Pro názornost je vhodné grafické srovnání struktury konstrukčního (vývojově-akčního) výzkumu s empirickým výzkumem (viz obr. 1), které sestavil Reeves (2000). 


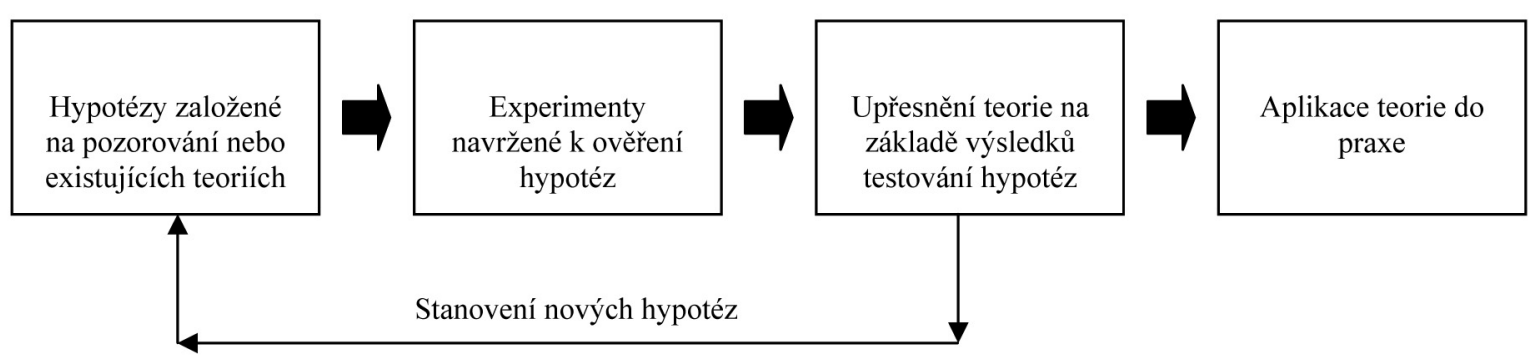

KONSTRUKČNÍ VÝZKUM

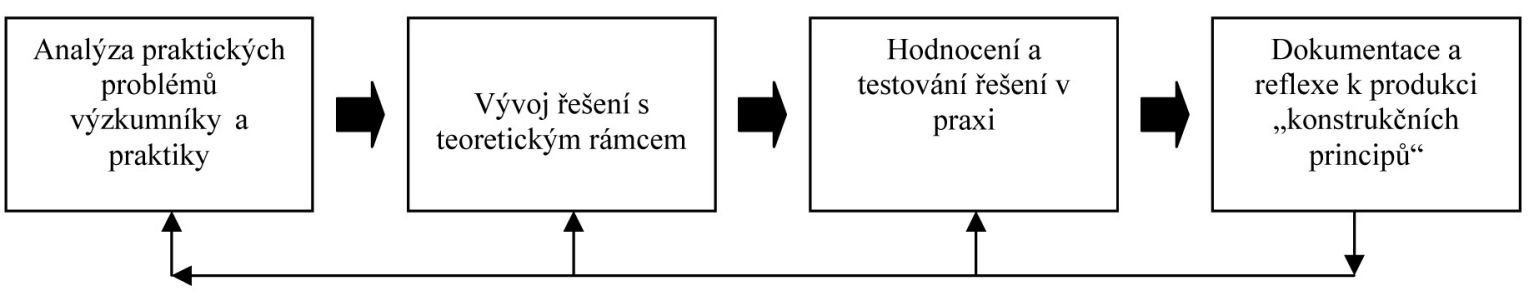

Upřesnění problémů, řešení a metod

Obr. 1: Empirický a konstrukční výzkum (upraveno podle Reevese, 2000)

Podrobný rozbor a srovnání empirického a konstrukčního výzkumu přesahuje cíle této studie. Hlavní výhodou konstrukčního výzkumu je jeho systémová provázanost s praktickou aplikací. Mnohdy se stává, že výsledky teoretického nebo empirického výzkumu, který je prováděn odděleně od praxe, nejsou učiteli chápány a využivány. Základním principem konstrukčního výzkumu je naopak těsná spolupráce mezi odborníky a učiteli. Ta je předpokladem vhodného výběru zkoumaných problémů a následného využití výstupů z výzkumu v praxi (Van den Akker et al., 2006).

\section{Př́́KLAD KONSTRUKČNÍHO VÝZKUMU V DIDAKTICE FYZIKY}

Pro snadnější porozumění podstatě konstrukčního výzkumu je vhodné uvést příklad tohoto výzkumu. Jde o ukázku konstrukčního výzkumu v didaktice fyziky, obsahově šíře přírodovědně zaměřenou na téma „Měření na lidském těle“.

Významnou motivační mezipředmětovou metodou (lépe technikou) je Aplikace fyziky v každodenním životě (Trna, Trnová, 2006). Do této sféry vzdělávacích obsahů patří především:

- Fyzika a lidský organismus. Sem řadíme poznatky mající vazbu na biologii, medicínu, ekologii, ochranu zdraví apod. Žáky a studenty seznamujeme s fyzikálními parametry lidského těla, které lze vyjádřit pomocí fyzikálních veličin, jednotek a zákonů. Významné jsou i informace o vnějších fyzikálních podmínkách, které jsou nutné pro udržení životních funkcí lidského organismu, včetně ochrany zdraví před negativními vlivy okolí (radioaktivita, ozónová díra, hluk, vibrace, výbuchy, nárazy, pády aj.). 
- Fyzika v domácnosti, při zábavě, sportu apod. Žáky a studenty můžeme výrazně motivovat vysvětlováním fyzikální podstaty běžně užívaných zařízení v domácnosti, jako jsou elektrické, tepelné a světelné zdroje, dopravní prostředky, ICT apod. Stále většího významu nabývají fyzikální informace o bezpečném, ekonomickém a ekologickém provozu těchto zařízení z pohledu fyziky. Mnoho informací s fyzikální tematikou se vyskytuje i v oblasti sportu a zábavy žáků a studentů.

Lidský organismus je pro většinu žáků a studentů mimořádně motivačním učivem, a to v širokém věkovém spektru. Je to dáno zejména trvalým uvědomováním si naší tělesnosti, měnící se funkce našeho organismu a zájmem o vlastní zdraví.

Budeme se zde věnovat vlastní struktuře tohoto konstrukčního výzkumu a uvedeme jeho jednotlivé etapy v souladu s Reevesovým schématem:

\section{Etapa 1. Analýza praktických problémů výzkumniky a praktiky}

Praktici - učitelé i didaktici fyziky - dlouhodobě zjištuují klesající zájem žáků a studentů o výuku fyziky. Obdobná situace je i v dalších přírodovědných předmětech (Kričfaluši, 2006; Škoda, Doulík, 2002; aj.). Je třeba nalézt vzdělávací obsahy a vytvořit vhodné metody (techniky), formy a prostředky, které budou žáky motivovat, vzbuzovat v nich především poznávací motivaci. Analýza praktického problému, kterým je demotivace žáků ve výuce fyziky, tak přinesla problém k řešení. Jeho jádrem se jeví výběr motivačních vzdělávacích obsahư a následný vývoj přislušných motivačních výukových metod, forem a prostředků, které by v žácích a studentech vyvolávaly především poznávací motivaci $k$ učení se fyzice. Takto je naplněna první etapa konstrukčního výzkumu, kterou je analýza a stanovení praktického problému.

\section{Etapa 2. Vývoj řě̌eni s teoretickým rámcem}

Teoretickým rámcem vývoje řešení problému se staly psychologické a pedagogické poznatky o teorii motivace, motivačních metodách aj. Při vlastním vývoji řešení problému byly použity různé metody a postupy. Patří k nim zejména: podrobná didaktická analýza biologických a medicínských poznatků o lidském organismu, vývoj jednoduchých postupů a pomůcek pro měření a experimentování na lidském těle, sestavování úloh, diskuse s experty v medicíně o vhodných poznatcích a metodách použitelných ve výuce atd. Jako ukázka vytvořených kurikulárních materiálů může sloužit žákovský experiment ve formě pracovního listu, jehož část uvádíme (určeno žákům ZS̆, věk 11-15 let).

\section{Plochá noha}

Popis: Rozměry chodidla jsou zjištovány při diagnostice poruch stavby nohou. Stavba nohy je důležitá pro pohybové stavy těla. Nejznámějši vadou je plochá noha. Jednoduché délkové měrení může tuto vadu odhalit. Ke vzniku ploché nohy přispívá nesprávná obuv. Proto je délka chodidla důležitá př̀ koupi obuvi. Pro jeji měrení použivaji prodejci speciálni délková měřidla, která jsou cejchována v různých jednotkách.

Pomůcky: otisk chodidla (plantogram), měrítko

\section{Experiment:}

1. Natřete chodidlo olejem (vodovou barvou, jen vodou) a stoupněte si na savý papír.

2. Změřte nejširšı $\left(w_{1}\right)$ a nejǔ̌ši část $\left(w_{2}\right)$ otisku chodidla.

3. Vypočítejte poměr $I=w_{2} / w_{1}$.

4. Vyhodnotte výsledek podle tabulky 4. 
Tab. 4: Plochá noha - měření

\begin{tabular}{|l|l|}
\hline \multicolumn{2}{|c|}{$I=w_{2} / w_{1}$} \\
\hline Normální noha & $I=$ méně než 0,45 \\
\hline Začínající plochá noha & $I=0,45$ \\
\hline Plochá noha & $I=$ více než 0,45 \\
\hline
\end{tabular}

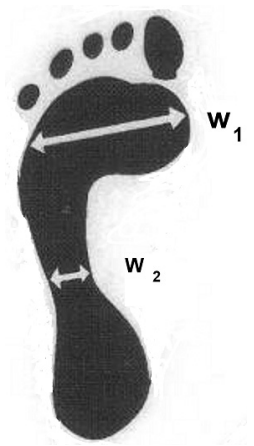

Obr. 2: Měření ploché nohy

\section{Etapa 3. Hodnoceni a testování řě̌eni v praxi}

Zejména pomocí akčního výzkumu ve školském terénu byla ověřována vhodnost a efektivnost jednotlivých motivačních metod, forem a prostředků vytvořených na tématu lidský organismus (zjednodušeně lidské tělo). Postupně byly do akčního výzkumu vkládány jednotlivé dílčí i komplexnější metody, formy a prostředky. V rámci reflexní fáze akčního výzkumu byly k hodnocení a testování produktů řešení použity obvyklé diagnostické metody (pozorování žáků, analýza produktů žáků, dotazníky, pretestování a posttestování vědomostí a dovedností). Vytvořeny byly i speciální diagnostické metody, např. v podobě průzkumu motivační efektivity pomocí rodinného přírodovědného vzdělávání (Trna, Trnová, 2010). Aby došlo k co největšímu křížovému ověřování efektivnosti vyvinutých řešení, je vhodné kombinovat různé metody a nástroje testování.

Jako ukázku hodnocení uvádíme výsledky dotazníkového šetření u rodičů žáků (věk žáků: 11 let), kteří prováděli ve škole měření ploché nohy:

Dva týdny po realizaci Měrení ploché nohy ve školní výuce (bez domácí úlohy) byl distribuován rodičũ žáků dotazník. Dotazník obsahoval čtyři otázky. Odpovědi byly vyhodnoceny a zpracovány do následující tabulky 5.

Výsledky výzkumu potvrdily efektivitu motivační techniky Měrení ploché nohy.

Tab. 5: Plochá noha - výsledky výzkumu

\begin{tabular}{|l|l|c|c|c|}
\hline & $\begin{array}{l}\text { Otázky pro rodiče } \\
\text { Otázky pro rodiče }\end{array}$ & $\begin{array}{c}\text { Cetnost } \\
\text { odpovědí: ANO } \\
\text { (2006): (\%) }\end{array}$ & $\begin{array}{c}\text { Cetnost } \\
\text { odpovědí: ANO } \\
\text { (2009): (\%) }\end{array}$ & $\begin{array}{c}\text { Počet vrácených } \\
\text { dotazníku் } \\
\text { (2006/2009): }\end{array}$ \\
\hline 1 & $\begin{array}{l}\text { Znáte nějakou } \\
\text { jednoduchou metodu } \\
\text { pro zjištění ploché } \\
\text { nohy? }\end{array}$ & 68 & 65 & $75 / 80$ \\
\hline 2 & $\begin{array}{l}\text { Naučili jste se tuto } \\
\text { metodu od svého } \\
\text { ditěte? }\end{array}$ & 60 & 62 & $75 / 80$ \\
\hline 3 & $\begin{array}{l}\text { Změřili jste si nohu } \\
\text { pomocí této metody? }\end{array}$ & 24 & 30 & $75 / 80$ \\
\hline
\end{tabular}


Etapa 4. Dokumentace a reflexe $k$ produkci „konstrukčních principü“ Etapa reflexe je zásadní součástí konstrukčního výzkumu, která jeho oprávněnost potvrzuje. V této fázi je třeba se vrátit k původním výzkumným problémům a zjistit, jestli vytvořené, testované a hodnocené řešení je či není skutečně řešením těchto problémů. Reflexe vychází z dat získaných ve třetí etapě a uvádí je do souvislostí.

$\mathrm{V}$ našem př́ípadě bylo problémem zvýšení motivace žáků k fyzikálnímu (přrírodovědnému) vzdělávání. Základem pro reflexi jsou data, jež byla získána především z akčního výzkumu. Zde je třeba stavět na těch datech, která ověřují zvýšení motivace žáků. Nárůst motivace žáků potvrdily především výsledky žákovských a učitelských dotazníků, vliv motivace na efektivitu výuky ověřují didaktické testy. Využili jsme i další metody, např. pozorování a dotazníky v rámci rodinného fyzikálního vzdělávání.

Finální částí této etapy konstrukčního výzkumu je zobecnění výsledků vývoje nových postupů, technik a nástrojů, vedoucích k produkci „konstrukčních principư Jde tedy o syntézu obecných zásad, jak žáky a studenty motivovat pomocí speciálních vzdělávacích obsahů, jako je lidský organismus. Tyto nově objevené zásady je možno stručně vyjádřit takto:

- Vhodnými kritérii pro výběr motivačních obsahů jsou: praktická aplikace poznatků a dovedností $v$ denním životě, interdisciplinární témata, jednoduché žákovské experimentování.

- Je třeba maximálně využívat žákovské prekoncepce s dưrazem na rozvoj pozitivních prekoncepcí a překonávání miskoncepcí.

- Jako zásadní opatření se jeví podnícení a rozvoj kreativity žákư i učitelů v př́rodovědném experimentování.

Jak bylo na začátku zdůrazněno, konstrukční výzkum a zejména jeho konkrétní produkty jsou určeny pro praktickou aplikaci ve výuce. Proto je třeba bez prodlení implementovat vytvořené metody, formy a prostředky do výuky a do př́ipravy učitelů. Obé jsme realizovali tak, že některá měření a experimenty prováděné na lidském těle jsme zařadili do učebnic (Matyášek et al., 2004). Problematiku měření na lidském těle jsme současně vložili do pregraduální přípravy učitelů př́rodovědy na prvním stupni ZŠ i učitelů fyziky a př́rodopisu na druhém stupni ZS̆.

Výzkum se stává výzkumem, pokud jsou jeho výstupy publikovány a mají ohlas v odborné veřejnosti. To jsme realizovali zařazením této problematiky do několika mezinárodních výzkumných projektů a do našich příspěvků na mezinárodních konferencích (Trna, Trnová, 2008; Trna, Trnová, 2010, aj.).

\section{ZÁvĚR}

Prezentovaná studie je zamýšlena především jako vstup do širší diskuse v přírodovědných didaktikách. Je zřejmé, že je třeba v budoucnu mnohem podrobněji popsat vlastní metodu konstrukčního výzkumu s jeho historickým vývojem a zasazením do systému metodologie př́rodovědných didaktik. Nabízí se řada výzkumných problémů, jako např. propojení konstrukčního výzkumu a praxe, vazba aktuálního paradigmatu př́rodovědných didaktik a konstrukčního výzkumu, vztah konstrukčního a akčního výzkumu, zařazení prvků konstrukčního výzkumu do profesní př́ípravy učitelů atd. 
Rozvoji konstrukčního výzkumu v přírodovědných didaktikách může bránit dosavadní odlišné aplikované výzkumné paradigma, zúženě vedoucí jen k empirickému a teoretickému výzkumu. Je třeba uvažovat ve směru posunu paradigmatu výzkumu (Kuhn, 1970). Konstrukční výzkum by měl v přírodovědných didaktikách získat a obhájit své rovnocenné a oprávněné postavení.

Relativní výhodou je současná situace dosud plně nestabilizované výzkumné metodologie př́rodovědných oborových didaktik, což umožňuje, aby při implementaci konstrukčního výzkumu došlo k jeho rychlému rozvoji a aplikaci.

\section{LITERATURA}

KRIČFALUŠI, D. Podpora zájmu mládě̌e o studium př́rodovědných oborů. Závěrečná zpráva o řešení Rozvojového projektu MŠMT č.615/1. Ostrava : Ostravská univerzita, 2006.

KUHN, T. S. The structure of scientific revolutions. Chicago, IL : The University of Chicago Press, 1970.

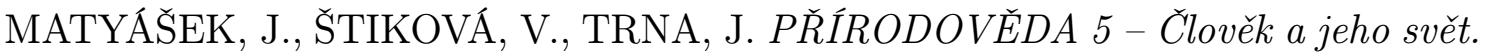
Učebnice pro 5. ročník Zঙ̆. Brno : Nová škola, 2004.

MERRILL, M. D., DRAKE, L., LACEY, M. J., PRATT, J. Reclaiming instructional design. Educational Technology, 1996, roč. 36, č. 5, s. 5-7.

REEVES, T. C. Enhancing the Worth of Instructional Technology Research through Design Experiments and Other Development Research Strategies. Paper presented on April 27, 2000 at Session 41.29, International Perspectives on Instructional Technology Research for the 21st Century, a Symposium sponsored by SIG/Instructional Technology at the Annual Meeting of the American Educational Research Association [online]. New Orleans, LA, USA [cit. 2011-04-12]. Dostupný z WWW:

$\langle$ http://it.coe.uga.edu/treeves/AERA2000Reeves.pdf $\rangle$.

REEVES, T. C. Design research from the technology perspective. In AKKER, J. V., GRAVEMEIJER, K., MCKENNEY, S., NIEVEEN, N. (eds.). Educational design research. London : Routledge, 2006, s. 86-109.

STOKES, D. E. Pasteur's quadrant: Basic science and technological innovation. Washington, DC : Brookings Institution Press, 1997.

ŠKODA, J., DOULIK, P. Změny učebních činností - nezbytný předpoklad modernizace výuky chemie. In Acta Facultatis Paedagogicae Universitatis Tyrnaviensis. Séria D. Supplementum 1. Trnava : Trnavská univerzita, 2002, s. 111-117.

TRNA, J. Nastává éra mezioborových didaktik? Pedagogická orientace, 2005, roč. 15 , č. 1 , s. 89-97.

TRNA, J., TRNOVÁ, E. Cognitive Motivation in Science Teacher Training. In Science and Technology Education for a Diverse Word. Lublin : M. Curie-Sklodovska university press, 2006, s. 491-498.

TRNA, J., TRNOVÁ, E. Family science and technology education as a new teaching and learning strategy for all including gifted students. In XIV. IOSTE Symposium. Socio-cultural and human values in science and technology education. Ljubljana: Institute for innovation and development of University of Ljubljana, 2010, s. 143-1 149. 
TRNA, J., TRNOVÁ, E. Safety of the Human Body in Hands-on Science Experiments. In Selected Papers on Hands-on Science. Braga : Associacio Hands-on Science Network, Vila Verde, Portugal, 2008, s. 572-579.

VAN DEN AKKER, J., GRAVEMEIJER, K., MCKENNEY, S., NIEVEEN, N. Educational design research. London : Routledge, 2006.

\section{PODĚKOVÁNí}

Studie byla zpracována $\mathrm{v}$ rámci řešení projektu 7. rámcového programu EU 266589 „PROFILES - Professional Reflection-Oriented Focus on Inquiry-based Learning and Education though Science“ a projektu MŠMT ČR MSM 0021622443 „Speciální potřeby žáků v kontextu Rámcového vzdělávacího programu pro základní vzdělávání".

doc. RNDr. Josef Trna, CSc. - E-mail: trna@ped.muni.cz katedra fyziky PdF MU

Poříčí 7, 60300 Brno, Česká republika 